\title{
THE RELATIONSHIP BETWEEN VIOLENCE SHOWS ON TELEVISION AND BULLYING BEHAVIORS AMONG STUDENTS
}

\author{
Ade Hernawati', Mamat Ruhimat ${ }^{2}$, Sapriya³ \\ 1ade.hernawati@student.upi.edu, ${ }^{2}$ mamatruhimar@upi.edu, ${ }^{3}$ ksapriya@yahoo.com \\ 1,2,3,Pendidikan Ilmu Pengetahuan Sosial, Universitas Pendidikan Indonesia
}

Submitted

July 24, 2019

\author{
Revised \\ December 23, 2019 \\ https://doi.org/10.17509/ipis.v28i2.18673 \\ Accepted \\ December 23, 2019
}

\begin{abstract}
This research is motivated by the increasing frequency and variety of violence on television. The show was consumed by many people, including junior high school students. The problem that arises is that many junior high school students are watching. The purpose of this study is to describe the shows of violence on television and bullying behavior among students in schools, and analyze the relationship of television violence to students' bullying behavior in schools. The research subjects were students of Majalengka 6 Middle School. Based on the hypothesis and the type of data used, testing will use a nonparametric statistical test. The reason for using this statistical test is because the data taken is in the form of nominal and ordinal data. The analysis uses the Spearman rank correlation test. The results of the study show that the description of violent shows on television, bullying behavior is included in the low category. There is a significant relationship between the display of violence on television and the bullying behavior of students at school.
\end{abstract}

Keywords: Impressions of Violence on Television, and Bullying Behavior

\begin{abstract}
ABSTRAK
Penelitian ini dilatarbelakangi oleh adanya frekuensi tayangan kekerasan di televisi yang semakin banyak dan variatif. Tayangan tersebut dikonsumsi oleh banyak orang, termasuk oleh siswa SMP. Masalah yang muncul yaitu banyak siswa SMP yang menonton. Tujuan penelitian ini untuk mengetahui gambaran tayangan kekerasan di televisi dan perilaku bullying di kalangan siswa di sekolah, dan menganalisis hubungan tayangan kekerasan di televisi terhadap perilaku bullying siswa di sekolah. Subjek penelitian adalah siswa SMP Negeri 6 Majalengka. Berdasarkan hipotesis dan jenis data yang digunakan, pengujian akan menggunakan uji statistik nonparametrik. Alasan menggunakan uji statistik ini dikarenakan data yang diambil berupa data nominal dan ordinal. Adapun analisisnya menggunakan uji korelasi rank spearman. Hasil penelitian menunjukkan bahwa gambaran tayangan kekerasan di televisi, perilaku bullying termasuk dalam kategori rendah. Ada hubungan yang signifikan antara tayangan kekerasan di televisi terhadap perilaku bullying siswa di sekolah.
\end{abstract}

Kata Kunci: Tayangan Kekerasan Di Televisi, Dan Perilaku Bullying

\section{INTRODUCTION}

Bullying refers to violence acts that are practiced repeatedly that involves physical strengths performed by the actors of bullying and the victims. Someone can be categorized as a victim of bullying when $s / h e$ is exposed repeatedly from time to time to a 
negative behavior by a person or more [1]. Bullying behavior can result several negative impacts to a victim that includes physical and psychological impacts, such as trauma feeling, injury, and even death [2]. In addition, victims of bullying tend to face more psychological impacts for instance, loneliness, anxiety, depression that may also affect their academic achievement [3].

Nowadays, the level of bullying behavior in Indonesia has been categorized at a level to be worried about. According to the data gained from Commission of Children Protection of Indonesia (KPAI), there have been around 253 cases of bullying that consists of 122 bullying cases where children become victims and 131 bullying cases where children become the actor of bullying in the last 6 years [4]. This data has no difference with data gained from Ministry of Social who found that up to June 2017, there have been 967 cases that are reported to the Ministry of Social, where 117 cases of them are cases of bullying [5]. A report of study under the same theme also revealed that there are around $67.9 \%$ of students at senior high school and $66.1 \%$ students at junior high school in three big cities including Jakarta, Yogyakarta, and Surabaya have been become victims of bullying.

There are several factors that may affect an increasing numbers of bullying among teenagers at schools, one of them is the increasing frequency of watching violence shows, especially on television. Today, almost every family has television and watch television at their home. The shows on television are diverse, begin from shows relating to education, information and news, and also entertainment. In other words, television may give various benefits that need to be known by the audiences, such as important and recent news, education, and knowledge, however, on the other hand, television may consist of shows that display shows or information that are less educated for the audience, especially teenagers, which in turn can give negative impact to them, such as shows that display violence acts that can be seen in minidramas, films, or news.

Television shows that consist of violence keep increasing day by day. For instance, television drama entitled Anak Langit tends to show violence acts and intimidation, such as scenes of intimidating other people by using various tools, and this drama is displayed frequently on television. Another drama television, entitled Sepatu super, also shows bullying behavior, one of them is in the form of verbal bullying, when someone is free to insult someone' physical condition, or do body shaming. In addition to drama television, there are also variety shows that tend to perform acts of bullying. A variety show entitled Pagi Pagi Pasti Happy that is broadcasted on January 2019 that display the co-host and the guest quarreled and they are involved in a fight. This episode finally attracts responses from the audience to urge Commission of Broadcasting of Indonesia (KPI) to ban the show. This is strengthen by emergence of survey result of KPI that can be seen in the cart below:

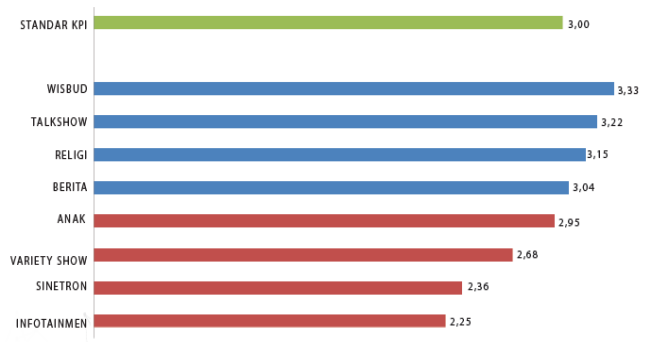

Source: KPI (www.kpi.go.id) As can be seen in the cart above, result of survey of Indonesian 
Broadcasting Commission in the 2nd period on June-October 2018 shows that there are 4 categories of TV broadcasts that are categorized as qualified with index $\geqslant 3$, that include tourism and culture programs (index 3.33), talkshow (index 3.22), religious shows (index 3.15) and news (index 3.04). Meanwhile, television drama and infotainment's index are still far below program quality standard that has been determined by KPI.

Problems arise when many children watch TV shows or programs that haven't fulfilled the program quality standard of $\mathrm{KPI}$. One of examples if it is viewed based on program quality indicator, the 2nd period survey result in 2018 showed that "no violence content" indicator has the lowest score compared to other indicators. If this condition continues to happen, there will be more possibilities for children to imitate what they have seen in the television to their peers in their daily life. As asserted by Tarde (cited in Supardan, D, 2011, p.140) that basically, social relation is begun by imitation process, even all kinds of human social life can not be separated from process of imitation.

Imitation process plays an important role in one's education and personality development. Imitation is able to motivate each individual to do kindness and make them have a healthy and good social interaction (Gerungan, 2004, p.63). Therefore, imitation process can make a good social interaction if behavior that is imitated or behavioral examples is good or positive behavior. On the contrary, when someone is exposed to negative behavior, they will also perform bad social interaction that in turn may cause bad implication.
Departing from this point of view, the study focuses on finding relationship between violence shows on television and students' bullying behavior at school.

\section{LITERATURE REVIEW Bullying Behavior}

In the last few years, bullying phenomenon at school attracts the researchers, educators, and social figures' attention. The founder of the movements against bullying is Profesor Dan Olweus from Unversity of Bergen that since the decade of 1970 in Scandinavian starts to focus on bullying phenomenon at school, that is called later as school bullying. The word bullying comes from English word that is word of bull means bull, a kind of animal that likes to plough here and there. This term is finally chosen to reflect destructive behavior. Further, according to Wiyani (2012, p.12). In Indonesian language, etymologically, the word bully means someone who likes to threat other weaker people. The term 'bullying' in Indonesia means menyakat (comes from the word sakat) and the doer of bullying is called penyakat. Menyakat means disturb, threat, snap other people.

Olwes defines bullying in the folowing general way: a student is being bullied or victimized when be or she is exposed, repeatedly an over time to negative action on the part of one or more other student [1]. Olwes points out that bullying is a negative behavior that can cause someone be in an uncomfortable condition or injured condition and it usually happened repeatedly.

Based on these definitions given by experts, it can be concluded that bullying can be referred to an aggressive behavior or behavior that hurts other

I86 Ade Hernawati, et al.| The Relationship Between .... 
people, a person or a group of people that is done repeatedly that can be done in physical, verbal, or psychological forms.

Bullying behavior, according to
Ribgy, has three integrated
characteristics that cover [6]:

a. There is an aggression behavior that makes the doer happy in hurting the victims. Bullying is desire to hurt other. This desire is shown in the form of actions that can cause other people hurt or suffered. This action is directly done by one particular person or a group of stronger, irresponsible people that is acted out repeatedly and happily.

b. The action is carried out between incomparable parties that can cause the victims feel depressed. Bullying also involve strength and power that are unequal between the doer and the victims that cause the victims have no ability to defense themselves effectively to go against the negative behavior they receive.

c. This behavior is conducted repeatedly and continuously. Bullying can be classified into an aggressive behavior proactive type that reflects intentional behavior to dominate, hurt, or get rid of something or someone, a negative behavior that shows power imbalance in terms of physic, age, cognitive competence, skills, and social status, that is performed repeatedly by one person or more to other people.

The doer of bullying can be defined based on the bullying definition that it is someone who has more power that enables him/her to control others who are considered lower in terms of power and other condition. The victims that have felt being a part of the group and a part of an influence and power imbalance will also influence this bullying behavior. The more unable the victims to go against the bullying behavior, the more frequent the bullying they will get. Besides, the bullying behavior can also be performed by classmates individually or in a group [7]. Bullying can take place not only in one particular place, but also in any places. According to Wiyani, bullying can take place in any place where social interaction exists [7], that includes:

a. School, or often called as school bullying. The bullying behavior can take place at school environment, especially in places that are free from both teachers and parents' supervision. Certain places that have more potency for bullying to take place are classrooms, school corridor, canteen, school yard, field, and toilet.

b. Workplace/office, or often called as workplace bullying. Workplace bullying is all kinds of behavior that tries to hurt other people or make others feel disadvantages in the same organization [8].

c. Internet or digital technology, or often called cyber bullying. The bullying behavior can also take place in the digital world by using technology of media, such as gadgets following the development of technology in the era [9]. The cyber bullying doer disturb other people through social media that cover Facebook, Twitter, Instagram, Path, and so on, through short messages, 
email and also meme that is currently popular. Meme is a new word that is known as a character from culture, that can reflect ideas, feeling, behavior, or action.

d. Political environment, that is known as political bullying. Political environment can also be made as a place to perform bullying behavior. This type of bullying is usually done to downgrade the opponent's reputation or to destroy a politician's credibility.

e. Military environment or often called as military bullying. The bullying behavior can also take place even in a military environment. Bullying is usually integrated into a recruitment program of new members by using mask of testing a new member's mental and physical power. In some cases of bullying practices also involve criminality actions, such as torture or prosecution.

f. In hazing moment.

Hazing is referred to an act of violence that is done by someone or a group of people that are more senior to their juniors.

In this current study, field of study only covers school area, where bullying is taken place not only in physical aspect, but also in many forms, such as verbal and psychological bullying.

The aspects of bullying behavior consist of:

a. Physical Bullying

Physical Bullying is a kind of bullying that can be seen clearly due to its physical conflicts that are performed by the doer to the victims of bullying. Physical bullying can take many forms of action such as hitting, pushing, and kicking) [10].

b. Verbal Bullying

Verbal Bullying is a kind of bullying that can be detected through our sense of hearing [11]. Examples of verbal bullying are: 1) insulting "You moron!", body shaming "You fat!", giving negative label "you Nerd", shouting, yelling. 2) shaming others in front of public "Hei, you are not one of us!", accusing, spreading rumors, making hoax or defaming.

c. Psychological Bullying

Psychological Bullying is the most dangerous kind of bullying since it can't be seen by our sight or sense of hearing if we are not that aware to detect it [12]. Some actions reflecting psychological bullying are: 1) Giving skepticism to others by intimidating / underestimating them, 2) shaming others in front of public and making terror.

There are several factors that can cause bullying to be happened, according to Ariesto that cover some aspects as follow [13]:

a. Family

The doer of bullying tends to come from broken home family: where parents frequently punish their children in inappropriate ways, situation of house is full of depressed, stress, aggression, and hostility feeling. The children will learn bullying behavior when they are aware of conflicts between their parents and will slowly imitate what

I88 Ade Hernawati, et al.| The Relationship Between .... 
they have seen and perform it to their peers. If there is no clear consequence from the surrounding toward their imitating behavior, they will consider that "they who have more power is allowed to do aggressive actions to other people and those aggressive actions is able to upgrade someone's status and power". From this point, the children will develop the bullying behavior.

b. School

School is an area that tends to ignore bullying phenomenon. This condition will worsen the bullying behavior of students where they will feel more free to make intimidation to their friends. Bullying behavior keeps developing rapidly when the school environment tend to give negative input to their students, for instance, not educated and destructive punishment to the students that may cause every member of school has no respect one to another.

c. Peers

Children when they interact with their peers at school or with their peers in their neighborhood are sometimes triggered to do bullying. Some children perform bullying in an attempt to prove their ability to be accepted by a certain group although they also don't feel comfortable by performing bullying.

\section{Violence Shows on Television}

Television is a media of delivering information that is quite preferred by the society from children to adults. This is due to the TV's ability to deliver information faster and more interesting compared to other kinds of media. Through television, the children are allowed to gain information and entertainment needed in a faster and more interesting ways that make them able to stay longer in front of the television.

The habit of watching television without ability to be creative may give negative impact, that it is able to make the children become passive. This is in line with George Garbner in his Cultivation theory.

Cultivation can be defined as planting, therefore Cultivation Theory is a theory that focuses on values cultivation. The Cultivation Theory is one of theories that is able to be used to explain impacts of media to the society. Cultivation Theory is a social theory that can observe long term effects of television on the society. This theory is one of mass communication theories that is developed by George Gerbner and Larry Gross from the University of Pennsylvania. The Gerbner Cultivation theory points out the cumulative effect of television that is able to portray a new reality according to the image of reality that is displayed in the television.

The violence shows on television according to Garbner is an expression or a real display from physical strength show off (with or without weapon/tools, including hurting themselves or other), actions of insisting other that make them suffered or injured, or other kinds of threats to others [14].

Television and printed media have an ability to shape bullying behavior patterns from shows they display or broadcast. Survey that is conducted by Saripah (cited in Lestari, at al, 2018) revealed that $56.9 \%$ children imitate scenes of films they have watched, and generally they also imitate 
movements (64\%) and conversation (43\%). This is in accordance with Gerbner who explains that television is not only considered as a window of information or reflection of events in our daily life, but also reflection of events in the world in general.

Watching activity is a process of activity that is consciously or unconsciously conducted to gain a kind of illusion on each individual's mind that will be influenced by violence displayed in the television. As stated by Juan Luís Benítez \& Fernando Justicia “... not all children who grow up watching large quantities of televised vio-lence end up becoming violent adolescents or adults; however, they do show more aggression when they are small and especially after they have watched violence. By contrast, children who watch programs with prosocial content are less aggressive, more cooperative and have more desire to share their things with other children" [15].

\section{METHODS}

The study was set as a quantitative study. The quantitative study can be employed to respond the relational variable questions in a research[16]. The site of the study is in SMP Negeri 6 Majalengka. The site was chosen due to several factors : 1) students come from rural areas that tend to watch TV more frequently; 2) there is a bullying phenomenon exists among students where students tend to use mean words to their peers, they also tend to insult, kick, hit others outside the school, intimidate others and etc.

The sample of population consists of 505 students of SMP Negeri 6 Majalengka. The samples were chosen by using Slovin technique since in the sample choosing process, the quantity of the sample need to be representative so that the result of the study can be generalized and the computation doesn't need number of samples table. Based on Slovin formulation, the quantity of sample needed to be involved is 83.47 that is finally made to be 100 respondents.

The data collection instrument that was employed in the study is questionnaire. Based on the formulated hypothesis and kinds of data that were employed, the study used a statistical non parametric test. The test was employed since the data used by the study were in the form of nominal and ordinal data. The data gained were then analyzed by using Spearman Rank of Correlation test to find degree of relationship between variables. In addition, the test will also find whether the relationship is significant or not.

\section{RESULTS AND DISCUSSION}

The findings of the study give a description about violence shows in the television. In this variable, the description cover items of kinds shows, frequency of watching television, duration of watching television, and the choosing of violence shows program in the television. In general, students in SMP Negeri 6 Majalengka tend to watch television drama compared to other television program. There are several reasons that make the television drama is more preferred by respondents of the study that cover: the message is relevant to the audience's social reality, the message reflects the values of tradition and culture, and the message are derived from conflicts that also happen in the real society setting [17].

Frequency of watching TV among students is categorized into a low category, where 52 respondents are in the low category. This means that they don't intensely watch TV shows

190 Ade Hernawati, et al.| The Relationship Between .... 
every day, but they only watch certain shows.

Duration of watching television among students of SMPN 6 Majalengka is also classified into low category. If it is viewed from the correlation between frequency and duration, the correlation exists. Results of Spearman's correlation between frequency and duration is $r=0,638 * *$ where it can be categorized as strong degree of relationship, with $p=0,000$. From this result, it can be concluded that there is a significant and strong relationship between frequency and duration of watching television. The more frequent the students watch TV, the longer the duration they will spend in watching TV.

Based on the computation, students in SMP Negeri 6 Majalengka are categorized into a high category in choosing violence shows on television, that is up to $58 \%$. This finding can be categorized into high because based on survey result conducted by KPI the quality of TV shows in Indonesia are still considered as low, especially on television drama and variety show.

Tabel 1. Correlations

\begin{tabular}{|c|c|c|c|c|}
\hline \multicolumn{5}{|c|}{ Tabel Correlations } \\
\hline & & & $\mathrm{X} 1$ & $\mathrm{Y}$ \\
\hline \multirow{8}{*}{$\begin{array}{l}\text { Spearman } \\
\text { 's rho }\end{array}$} & \multirow{4}{*}{$\mathrm{X} 1$} & Correlation & 1,000 &, $255^{*}$ \\
\hline & & Coefficient & & \\
\hline & & Sig. (2-tailed) & &, 010 \\
\hline & & $\mathrm{N}$ & 100 & 100 \\
\hline & \multirow{4}{*}{ Y } & Correlation &, $255^{*}$ & 1,000 \\
\hline & & Coefficient & & \\
\hline & & Sig. (2-tailed) &, 010 & \\
\hline & & $\mathrm{N}$ & 100 & 100 \\
\hline \multicolumn{5}{|c|}{$\begin{array}{l}\text { *. Correlation is significant at the } 0.05 \text { level } \\
\text { (2-tailed). }\end{array}$} \\
\hline
\end{tabular}

Based on the data analysis, it is shown that $r$ value $=0,255^{*}$ with significant level of $p=0,010$, therefore $p$
$<0.05$ that make $\mathrm{Ho}$ is rejected. This means that there is a significant relationship between violence shows on television and students' bullying behavior at school.

Afterwards, the study also tries to find relationship between each indicator in the variable $\mathrm{X} 1$ and $\mathrm{Y}$, that cover:

a. Students' bullying behavior has no correlation with kinds of shows, $r=$ 0,001

b. Students' bullying behavior has a weak correlation with frequency of watching TV, $r=0,269 * *$

c. Students' bullying behavior has no correlation with duration of watching television, $r=0,140$

d. Students' bullying behavior has a weak correlation with violence shows choice, $r=0,259^{* *}$

Television is a potential and effective media that can be used to influence society. This is in line with Garbner's Cultivation Theory. Cultivation means planting, this means that Cultivation theory focuses on cultivating values. This theory can be used as a theoretical foundation to reveal and explain the impacts of media to the society.

There are several positive impacts of the media, especially television such as to deliver information to the society, to give entertainment, and etc. However, television can also give negative impacts, one of them is it is able to shape bullying behavior patterns of the society through the TV shows that display negative or violence contents. This is in line with study of Saripah (cited in Lestari, et al, 2018) who revealed that $56,9 \%$ children imitate actions in films they have watched, $64 \%$ of them imitate movement, meanwhile 
$43 \%$ children also imitate the dialogue they have heard. This finding is also in accordance with Gerbner's cultivation theory, further, television is not only considered as window of information and a reflection of event happened in our daily life, but it is also a reflection of what happened in the world itself. Description of violence shows in the television is a symbolic message about law and regulation.

In line with study of Saripah, the current study also proves that there is a correlation between violence shows on television with students' bullying behavior with $r$ value $=0,255^{*}$ significance level $p=0,010$, therefore $p<$ 0,05 that makes $\mathrm{HO}$ is rejected. Accordingly, the more violent the television shows, the more aggressive the students will be (Myers, 2012, p. 96). The relationship between television and violence shows on television is influenced by several factors, some of them are frequency of watching factor and violence shows on television choices. Findings of the study reveals that there is a positive and significant relationship between frequency of watching television and students' bullying behavior $(r=0,269$; $p<0,007)$. This finding implies that the more frequent the students watch television, the higher performance of bullying behavior among students. In addition, the choice of violence shows on television also has positive and significant relationship with students' bullying behavior. This also implies that the higher the choice of violence shows, the higher performance of bullying behavior they do. To conclude, the findings of the study reveal that the more frequent the students watch television and the higher the choice of violence shows, the higher performance of bullying behavior they do. This is supported by Bushman who asserts that "Characteristic of strong aggressive behavior has is influenced by strong preference and habit of watching violence shows through several media" [18].

Bushman further states that “... an aggressive individual tends to prefer shows that consists of violence that can strengthen their aggressive behavior/tendencies" [18]. To attract more audience, television shows usually display scenes that consist of physical, verbal, and psychological violence in order to provoke the audience's emotion to make them watch the same show over and over.

Television shows nowadays still expose violence aspects, as found by the KPI survey annually. Based on the survey results on the index of quality of television shows program in 2018, KPI then determines standard of quality index of television shows program that is $\geq 3$. The results revealed that tourism and culture, religious talk show, and news program are considered qualified since their index are more than standard index. Meanwhile, children shows, variety shows, drama television, and infotainment program index are still below the standard index that has been determined by KPI.

If we look at survey results of $\mathrm{KPI}$, children TV shows program has index of quality of indicator "no violence content" only 2.92. This is an ironic situation because children program that should actually give children more educated contents consists of more violence acts that are able to give children negative impacts, for example shaping the children's behavior to be aggressive. As stated by Bandura that aggression that is performed in daily life or in TV shows can influence the

I92 Ade Hernawati, et al.| The Relationship Between .... 
audience to have aggression behavior, especially for teenagers or children".

Beside children TV program, the index of quality of variety show and television drama also are also below standard of index quality program determined by KPI. There are several aspects explaining why television drama aren't appropriate from religious point of view according to Iswahyuni [19] that cover:

a. Morality aspect, this usually covers aspects of values, good or bad, and right or wrong. Good or appropriate behavior but it is considered as bad, in the television drama is merely displayed without giving bonding that the behavior is wrong, for example giving respects to parents or teachers. This is frequently displayed in many television dramas.

b. Sexuality aspect, television dram also often show aspect of sexuality through the clothes that are worn by the actors or actress, and also ways of showing affection or love that tend to be vulgar and that is not appropriate to be watched by children. From holding hands, kissing, hugging affectionately, just like husband and wife.

Violence aspect, actor and actress in the television drama are directed to solve problems by violent actions such as hitting, kicking, strangling, and etc.

c. Behavior aspect, this can be seen through students' behavior that tend to be permissive and free from school regulation. The students in the television drama are brave to show their tattoos, bright-colored hair, and perform brutality behavior, unbutton shirt of uniform, and etc. d. Language aspect, there are various languages used in the television drama that tend to use rude languages to insult others as a reflection of hatred, jealousy, and malice to the opponent actor/actress.

Watching activity is a process of activity that is consciously or unconsciously conducted to gain a kind of illusion on each individual's mind that will be influenced by violence displayed in the television. Media nowadays are being questioned about their ability to deliver information because today, the television consists of more violence contents that are directly and frequently displayed. These then become examples to the viewers that will be imitated later by the students that makes them have bullying behavior. However, not all students who watch television perform bullying behavior.

As stated by Juan Luís, Benítez \& Justicia Fernando that “... not all children who grow up watching large quantities of televised vio-lence end up becoming violent adolescents or adults; however, they do show more aggression when they are small and especially after they have watched violence. By contrast, children who watch programs with prosocial content are less aggressive, more cooperative and have more desire to share their things with other children" [15].

Not all students who watch violence shows on television will grow to be aggressive individuals. However, they tend to show more aggression when they have watched violence shows. On the other hand, when the children watch proportional content, they will grow to be more cooperative individuals and they who have willingness to share with others. 


\section{CONCLUSION}

Findings of study that was conducted to students of SMP Negeri 6 Majalengka revealed that there is a significant relationship between violence shows on television and peer group that is delinquent to the students' bullying behavior at school. According to the data analysis, results and discussion in the previous chapter, some conclusions can be drawn as follows:

The result of study showed that violence shows on television are chosen from various indicators, such as kinds of shows, frequencies, duration, and violence program choices. Results dealing with kinds of shows, most of students of SMPN 6 Majalengka watch television drama compared to variety shows, meanwhile frequency of their watching activities is categorized into low category, so is their watching duration. However, choice of violence television program is classified into a high category. Peer group that is delinquent is included as middle category, and bullying behavior is classified into low category.

There is a significant relationship between violence shows on television and students' bullying behavior at school. The more frequent students watch violence shows, the more frequent students perform bullying behavior at school.

\section{RECOMMENDATION}

Based on the discussion and conclusion above, one primary recommendation is made.

The study has proven that there is a significant relationship between violence shows on television and students' bullying behavior at school. Therefore, it is suggested to parents and teachers to give more attention to shows (films, dramas, games, and variety shows) that are watched by their children and also to watch their children behavior so as not to be the doer or the victims of bullying.

\section{REFERENCES}

[1] D. Olweus, "Bullying at School," 1994, pp. 97-130.

[2] B. A. Keliat, T. A. Tololiu, ovy H. C. Daulima, and E. Erawati, "Effectiveness Assertive Training of Bullying Prevention among Adolescents in West Java Indonesia," Int. J. Nurs., vol. 2, no. $1,2015$.

[3] T. Nansel, M. Overpeck, R. Pilla, W. R.- Jama, and undefined 2001, "Bullying behaviors among US youth: Prevalence and association with psychosocial adjustment," jamanetwork.com.

[4] D. A. Muthmainah, "Semakin Banyak yang Melaporkan Kasus 'Bullying," CNN Indonesia, 2017.

[5] L. Badriyah, "Sikap Mengontrol diri dalam menurunkan Kecenderungan Berperilaku Agresif Pada Remaja," J. Ilm. Syi'ar, vol. 18, no. 1, pp. 13-22, Feb. 2018.

[6] K. Rigby, "The relationship between reported health and involvement in bully/ victim problems among male and female secondary schoolchildren," J. Health Psychol., vol. 3, no. 4, pp. 465476, 1998.

[7] N. A. Wiyani, Save our children from school bullying. Jogjakarta: Ar-Ruzz Media, 2012.

[8] C. Rayner, "The incidence of workplace bullying," $J$. Community Appl. Soc. Psychol., 
1997.

[9] S. Hinduja and J. W. Patchin, "Bullying, cyberbullying, and suicide," Arch. Suicide Res., vol. 14, no. 3, pp. 206-221, Jul. 2010.

[10] J. Wang, R. J. Iannotti, and T. R. Nansel, "School Bullying Among Adolescents in the United States: Physical, Verbal, Relational, and Cyber," J. Adolesc. Heal., vol. 45, pp. 368375, 2009.

[11] D. Olweus, Bully at school: What we know and what we can do. Cambridge, 1993.

[12] L. Arseneault, L. Bowes, and S. Shakoor, "Bullying victimization in youths and mental health problems: 'Much ado about nothing'?," Psychol. Med., vol. 40, no. 5, pp. 717729, May 2010.

[13] A. Ariesto, "Pelaksanaan Program Antibullying Teacher Empowerment Program (TEP) Di Sekolah (Studi deskriptif program Teacher Empowerment Program," Universitas Indonesia, 2009.

[14] G. Gerbner, L. Gross, N. Signorielli, and M. Morgan, "Television Violence,
Victimization, and Power," Am. Behav. Sci., vol. 23, no. 5, pp. 705-716, May 1980.

[15] J. Luís Benítez, F. Justicia, J. L. Benítez, and F. Justicia, "Bullying: description and analysis of the phenomenon," Electron. J. Res. Educ. Psychol. No 9, vol. 4, no. 9, pp. 151-170, 2006.

[16] C. Williams, "Research Methods," vol. 5, no. 3, pp. 6572, 2007.

[17] W. Kuswandi, "Komunikasi masa: sebuah analisis isi media televisi," 1996.

[18] B. J. Bushman and C. A. Anderson, "Media violence and the American public: Scientific facts versus media misinformation," Am. Psychol., vol. 56, no. 6, pp. 477-489, 2001.

[19] E. Iswahyuni, "Pengaruh Kebiasaan Menonton Terhadap Perkembangan Perilaku Anak Usia Sekolah Dasar di SDN PaoPao Kecamatan Somba Opu Kabupaten Gowa,” p. 102, 2015. 